\title{
Structural Interpretation of the Mamfe Sedimentary Basin of Southwestern Cameroon along the Manyu River Using Audiomagnetotellurics Survey
}

\author{
Jean Jacques Nguimbous-Kouoh,, ${ }^{1}$ Eric M. Takam Takougang, ${ }^{2}$ Robert Nouayou, ${ }^{1}$ Charles \\ Tabod Tabod, ${ }^{1}$ and Eliezer Manguelle-Dicoum ${ }^{1}$
}

${ }^{1}$ Department of Physics, Faculty of Science, University of Yaoundé I, P.O. Box 812, Yaoundé, Cameroon

${ }^{2}$ Department of Earth Sciences, Simon Fraser University, 8888 University Drive, Burnaby, BC, Canada V5A1S6

Correspondence should be addressed to Jean Jacques Nguimbous-Kouoh, nguimbouskouoh@hotmail.fr

Received 25 January 2012; Accepted 8 February 2012

Academic Editor: F. Monteiro Santos

Copyright ( $) 2012$ Jean Jacques Nguimbous-Kouoh et al. This is an open access article distributed under the Creative Commons Attribution License, which permits unrestricted use, distribution, and reproduction in any medium, provided the original work is properly cited.

\begin{abstract}
Five audiofrequency magnetotelluric AMT soundings were collected northwest-southeast along the Manyu river in the Mamfe sedimentary basin of southwestern Cameroon. The soundings were performed with frequencies in the range 3 to $2500 \mathrm{~Hz}$ and covered a distance of approximately $28 \mathrm{~km}$. Sounding curves and geoelectric and geological sections were processed, and the results were compared with rocks' resistivity to characterize the lithostratigraphy of the eastern part of the basin. The results show above $1000 \mathrm{~m}$ depth, sedimentary layers with resistivities in the range of 1 to $100 \mathrm{Ohm}-\mathrm{m}$, which decrease with depth. We identified three types of sedimentary rocks: laterite-clay mixture, shale, and sandstones. Various faults were also identified, illustrating the structural complexity of the Mamfe basin, along the Manyu River.
\end{abstract}

\section{Introduction}

The geological studies of the Mamfe basin (southwestern Cameroon) were carried out for the first time by Le Fur [1], Dumort [2], and Paterson et al. [3]. These initial studies provided the framework for the first geological map of the area. The geophysical studies in the area integrate gravity works by Collignon [4], Fairhead and Okereke [5], Fairhead and Okereke [6], Fairhead et al. [7], Ndougsa-Mbarga [8], and Ndougsa-Mbarga et al. [9]. The geophysical studies also include audio-magnetotelluric (AMT) works by ManguelleDicoum et al. [10], Nguimbous-Kouoh [11], Nouayou [12], and Tabod et al., [13] to map subsurface resistivities.

The aim of this paper is to use AMT field data to characterize the shallow structure of the Mamfe sedimentary basin along the Manyu River. To achieve this, various interpretation techniques were employed. The sounding curves were interpreted to derive the stratigraphy under each AMT station. A pseudosection and geoelectric and geological resistivity sections were then derived along the AMT profile, to deduce the continuity of the subsurface layers and the distribution of associated electrical resistivities. The combination of geoelectrical sections and pseudosections enables a more thorough interpretation [11, 14-18]. The AMT profile has five stations: Ndwap (M1), Abonando (M2), Esagem1 (M3), Esagem2 (M4), and Baku (M5).

\section{Geology of the Study Area}

The Mamfe sedimentary basin is a rifting basin formed in response to the Gondwana break-up and subsequent separation of the South American and African plates. It lies on an NW-SE trending trough with a length of $130 \mathrm{~km}$ and a width of $60 \mathrm{~km}$ and constitutes a small prolongation of the Benue trough where important oil fields have been discovered (Figure 1(a)). The basin is favorable for the exploration of ores like lignite, lead, and zinc $[2,8,11,12,19-23]$. It is located between the latitudes $5^{\circ} 30^{\prime} \mathrm{N}$ and $6^{\circ} 00^{\prime} \mathrm{N}$, and longitudes $8^{\circ} 50^{\prime} \mathrm{E}$ and $9^{\circ} 40^{\prime} \mathrm{E}$ (Figure 1(b)), with average altitude ranging between 90 and $300 \mathrm{~m}$ above sea level. 


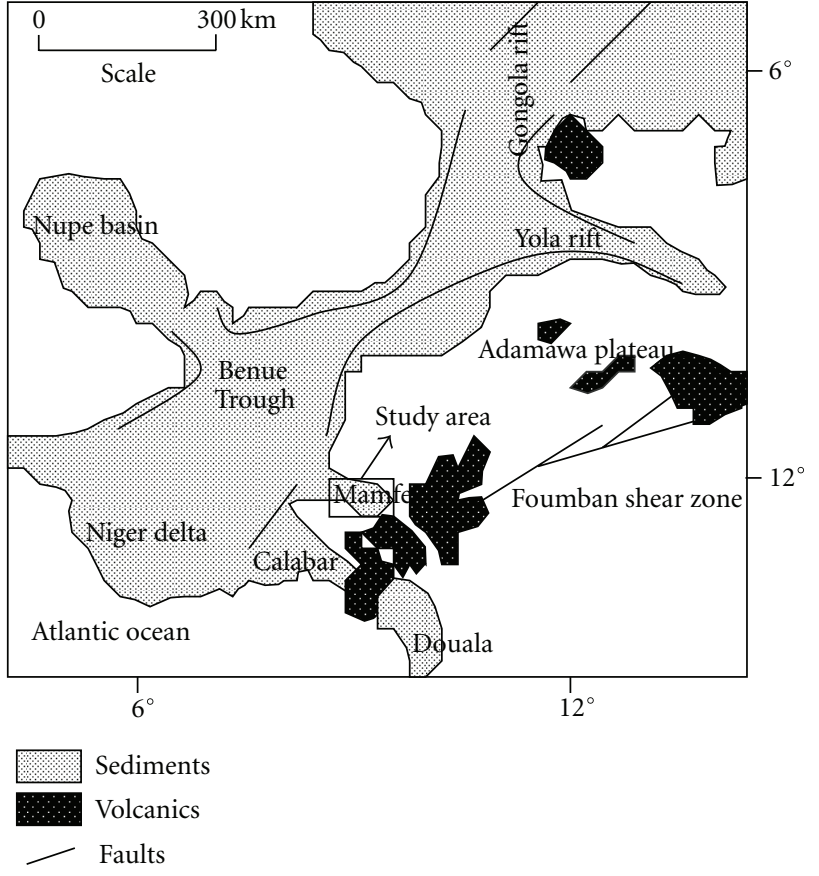

(a)

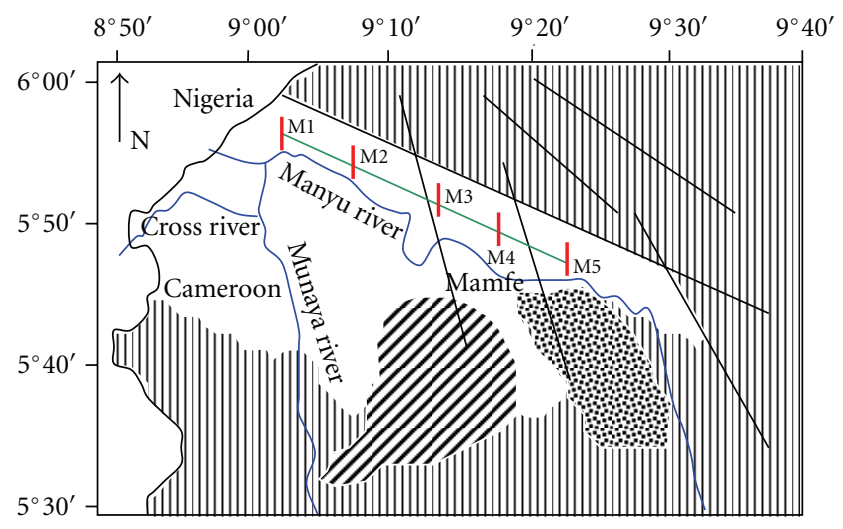

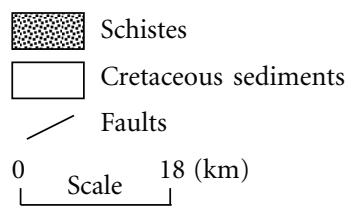

(b)

Figure 1: Geologic map of the study area. (a): Map showing the location of the study area and the location of rifts in the Benue Trough (from Fairhead et al. [7]). (b): Geologic map of the Mamfe basin and AMT stations from [20].

Figure 1(b) shows the available geological map. Some geological features have been extrapolated or withdraw. This is a preliminary geological map that was updated following several studies $[2,9,20]$. The geomorphology of the area is characterized by a succession of horst and grabens [2, 7-9, 20]. The basin is bordered by faults and rivers such as Manyu and Munaya which extend from Cameroon to Nigeria.
The lithology of the basin consists of a thick layer of sediments that impedes the identification and mapping of some major discontinuities at shallow depths. The sedimentary package lies on the Precambrian granite-gneiss basement. The sequence, from bottom to top, presents a succession of granites, schists, shales, sandstones, clays, and laterite (Figure 2). The stratification forms a sigmoid structure typical of a synclinal which is oriented E-W and its axes plunges $10^{\circ}$ to $20^{\circ} \mathrm{W}[2,7,20,22-24]$.

Le Fur [25] recognized five series of sedimentary rocks in the eastern part of the Mamfe basin (Figure 2), and these include from top to bottom [23]:

(i) cross River sandstone series,

(ii) clayey sandstone series,

(iii) upper conglomeratic sandstone series,

(iv) Manyu sandy clay series (This series is mineralized with galena, blende, and pyrite, as well as lignite or brown coal products),

(v) lower conglomeratic sandstone series.

\section{Review of the AMT Method}

The audiomagnetotelluric method (AMT) is based on the calculation of the transfer functions between the telluric and magnetic fields measured on the surface of the ground. These transfer functions define an impedance tensor $Z_{x y}$ that is calculated assuming a linear relationship between the geomagnetic field Hy (in gamma) and the telluric field Ex (in $\mathrm{mV} / \mathrm{km}$ ) resulting from the interaction between the solar wind and the earth magnetic field in the upper atmosphere $[26,27]$. The subsurface apparent resistivity is related to this impedance by the relation $\rho=0.2 / f \cdot\left|Z_{x y}\right|^{2}$. The apparent depth at a given frequency $f(\mathrm{~Hz})$ and for an apparent resistivity $\rho(\mathrm{Ohm}-\mathrm{m})$ is given by the relation $\rho(\mathrm{Km})=$ $0.503(\rho / f)^{1 / 2}[28-30]$. Electromagnetic waves at a given frequency penetrate deeper in resistive rocks than in conductive rocks. Therefore, by changing the frequency, different depth of the subsurface can be imaged. This constitutes a fundamental basis for the AMT method.

Processing of observed data (sounding curves) is based on best-fitting the observed data with the computed data. In order to mitigate the nonuniqueness of solution, a priori geological information of the study area is usually necessary. If the subsurface is isotropic, the telluric and magnetic fields are perpendicularly to one another, and the telluric field shows a shift of $45^{\circ}$ compared to magnetic field (advance in phase). When the subsurface is anisotropic, the telluric and magnetic fields are no more orthogonal, and the shift deviates from $45^{\circ}$. The apparent resistivity and the phase shift can be estimated in the direction of the telluric field ( $\rho \mathrm{aE}$ and $\Delta \varphi \mathrm{aE}$, resp.) and in the direction of the magnetic field ( $\rho \mathrm{aH}$ and $\Delta \varphi \mathrm{aH}$, resp.) $[31,32]$.

\section{Data Acquisition}

The data were collected with an audio-frequency resistivimeter [1], which measures the values of the electrical resistivity 


\begin{tabular}{|c|c|c|}
\hline Lithology & Description & Age \\
\hline & Basalts, syenites, and trachytes & Tertiary \\
\hline & Sandstones, arkosik, and conglomeratic & Cenomanian \\
\hline & Oolitic, shales with centimetric veinlets of lignite, and & \\
\hline & bituminous shales & \\
\hline & Conglomerates overlain by arkosic sandstones showing & \\
\hline & cross bedding & \\
\hline & Conglomeratic sandstones with arkosic cements & \\
\hline & arkosic sandstones & \\
\hline & Basement made up of granites schists and gneisses & Precambrian \\
\hline
\end{tabular}

FIGURE 2: Generalised stratigraphic column of the Mamfe Basin showing ages of units, lithology, and probable source rocks from Le Fur [25] and Eseme et al. [23].

and the apparent phase for twelve different frequencies $(2500$ to $3 \mathrm{~Hz}$ ). The stations were laid out with an equidistance of approximately $5 \mathrm{~km}$, due to irregularities of the relief and ease to equipment accessibility. The electrodes were positioned at each station on a surface area of about $10.000 \mathrm{~m}^{2}$ with two electrodes aligned in the N-S magnetic axis (Hy) and two in the E-W telluric axis (Ex). The location of the stations, and the directions of the telluric line, which was assumed to be parallel to the basin, were obtained with a compass and a GPS. Measurements were carried at five successive stations (M1-M5) between the localities of Ndwap (M1) and Baku (M5) (Figure 1(b)). The geographical coordinates that help locating these stations are shown in Table 1. The average-apparent resistivity and the average phase for each frequency were calculated to obtain a good image of the pseudosection and the geoelectric section. The formulas $\rho_{\mathrm{am}}=\sqrt{\rho_{\mathrm{N}-\mathrm{S}} \cdot \rho_{\mathrm{E}-\mathrm{W}}}$ for the average apparent resistivity and $\varphi_{\mathrm{am}}=1 / 2\left(\varphi_{\mathrm{N}-\mathrm{S}}+\varphi_{\mathrm{E}-\mathrm{W}}\right)$ for the average phase were used $[11,12,32]$. We applied the one-dimensional AMT principle: when two sounding curves measured in both telluric and magnetic directions along the main axes show similar apparent resistivity trends, 1D interpretation of average sounding curves is justified and the pseudosection and geoelectric section can be derived without any other errors beside those due to data quality $[11,12,14-16]$. The static shift was removed by compensating for site anisotropy [3337]. The data inversion was done using IPI 2 WIN and AMTINV software $[17,18]$.

\section{Results and Interpretation}

5.1. Interpretation of the Sounding Curves. The $1 \mathrm{D}$ models in Figure 3 show the sounding and phase curves at each station. The number of layers, thickness, and resistivity was derived from the best fit between experimental and theoretical curves. The data were interpreted with a maximum number of four layers, considering the sedimentation sequence and the lower resistivity of rocks in the area $[7,11,12]$. The number of layers at each station was controlled by the use of the root means square (RMS) misfit (0.006 to 0.20$)$ between the field and modeled data and by the use of a damping-mean $(0.71$ to 0.87 ).

The interpreted models show the subsurface resistivity of the basin, along the Manyu River, to a depth of about $800 \mathrm{~m}$. Overall, the first layer is relatively resistive (4-79 Ohm-m) with thickness of about 7 to $31 \mathrm{~m}$. The underlying second layer is less resistive ( 2 to $48 \mathrm{Ohm}-\mathrm{m}$ ) and extends between 66 to $250 \mathrm{~m}$ depth. The third layer has a thickness ranging between 250 and $600 \mathrm{~m}$ with electrical resistivities of about 1 to $3 \mathrm{Ohm}-\mathrm{m}$ and overlies the fourth layer, which has a resistivity of about 4 to 20 Ohm-m.

5.2. Interpretation of the Phase Curves. An important property of the phase is that it reacts slowly to variation in subsurface resistivities. Another application of the phase is that it is often used to measure the quality of the data $[38,39]$. In all the models of Figure 3, the phase curves are plotted as a function of the frequency. At high frequencies, the phase curves at Abonando (M2), Esagem1 (M3), and Baku (M5) stations are slightly below 45 degree, showing that the first layer is less resistive than the second. At low frequencies, the phase curves are slightly above 45 degree and imply that the third layer is increasingly conductive. However, the phase curves are greater than 45 degree or converge asymptotically towards 45 degree, in Ndwap (M1) and Esagem2 (M4). This shows that in these areas, the first layer is more resistive than the whole subsurface layers at all the frequencies. 


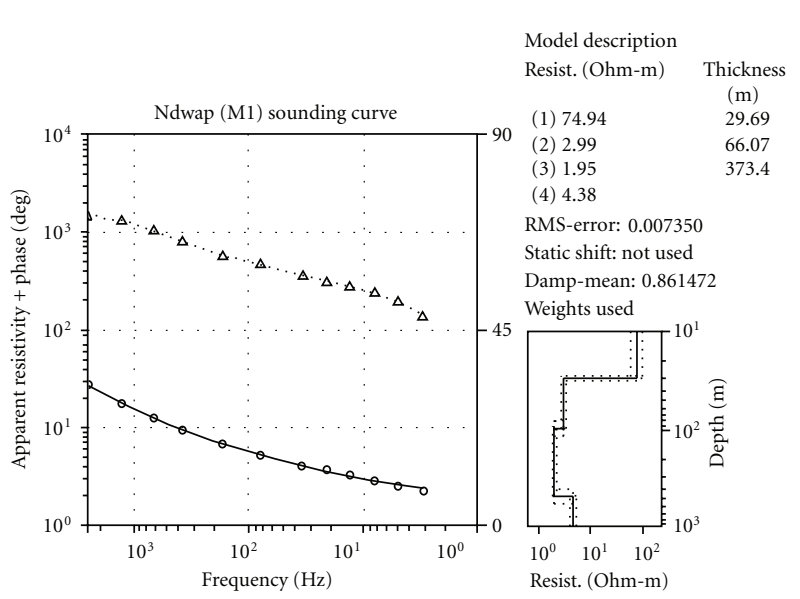

(a)

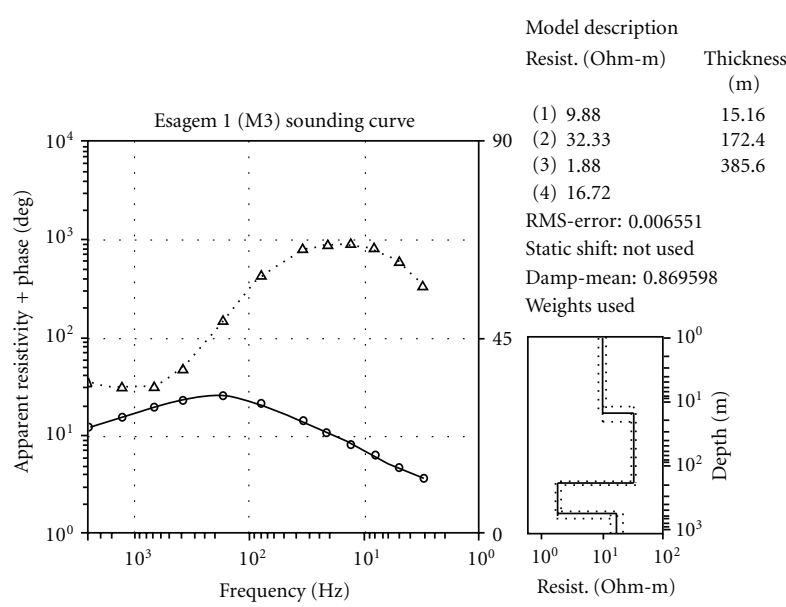

$\begin{array}{ll}\circ \text { Rhoa meas. } & \text { - Rhoa comp. } \\ \Delta \text { Phase meas. } & \text {.... Phase comp. }\end{array}$

(c)

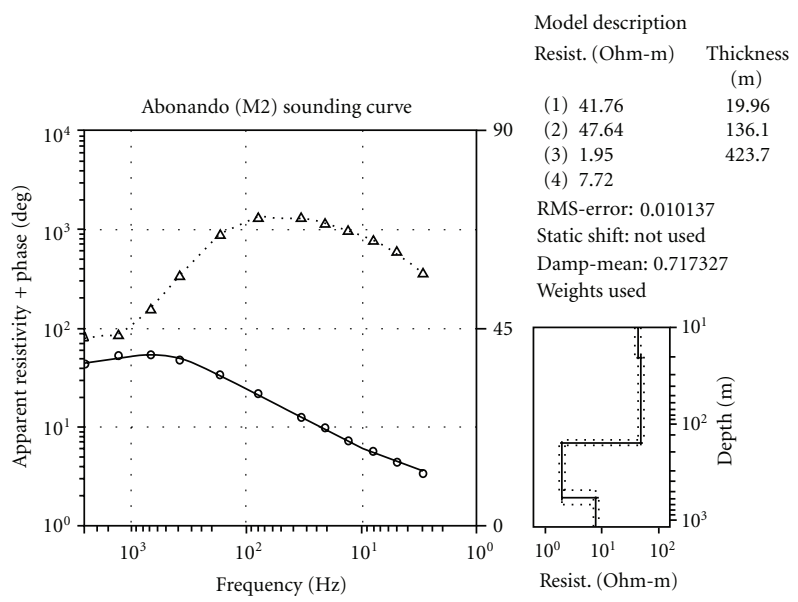

(b)

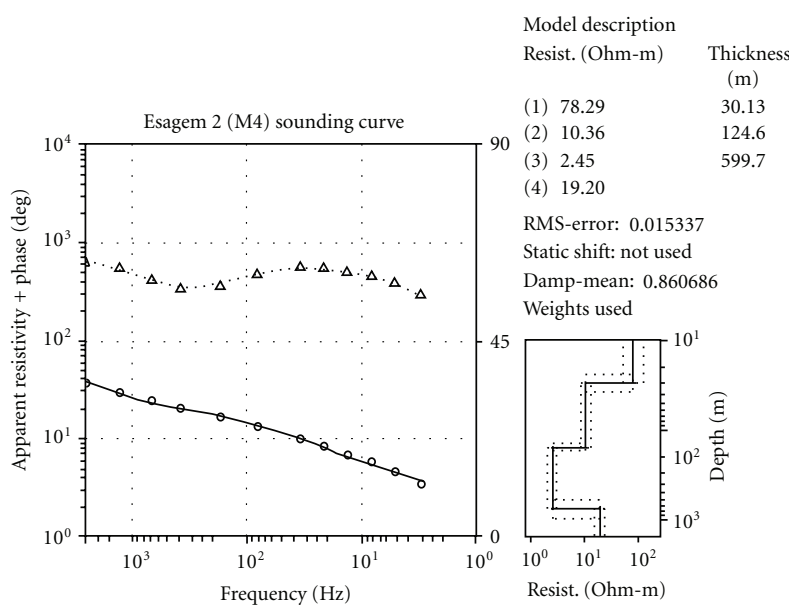

- Rhoa meas. - Rhoa comp.

(d)

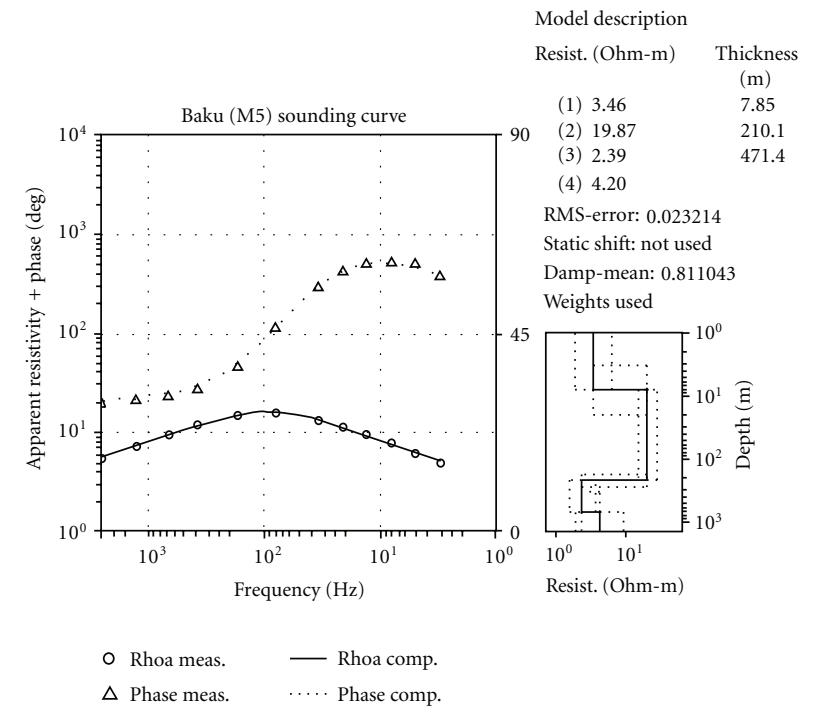

(e)

FIGURE 3: 1D modelling results of five stations. 


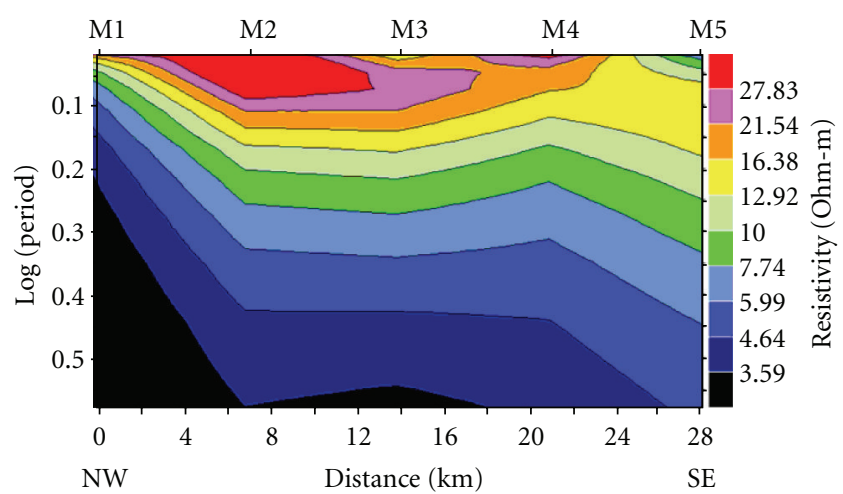

FIGURE 4: Derived pseudosection along the profile.

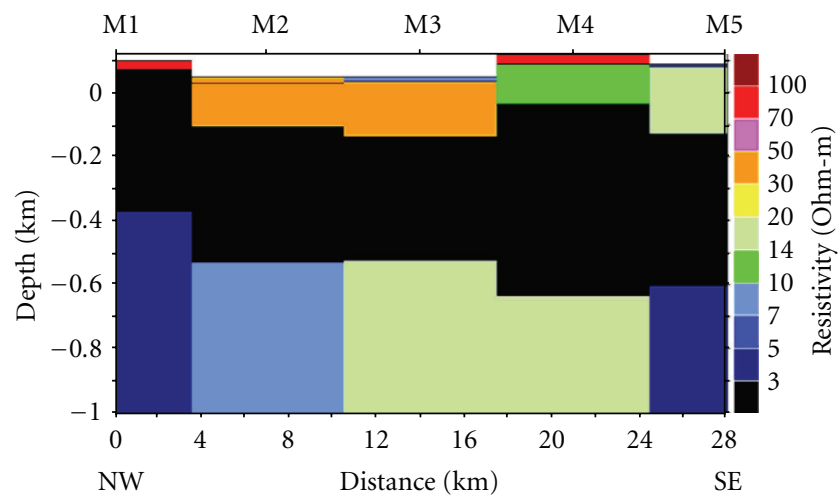

Figure 5: Geoelectric model derived from correlation of sounding curves along the profile.
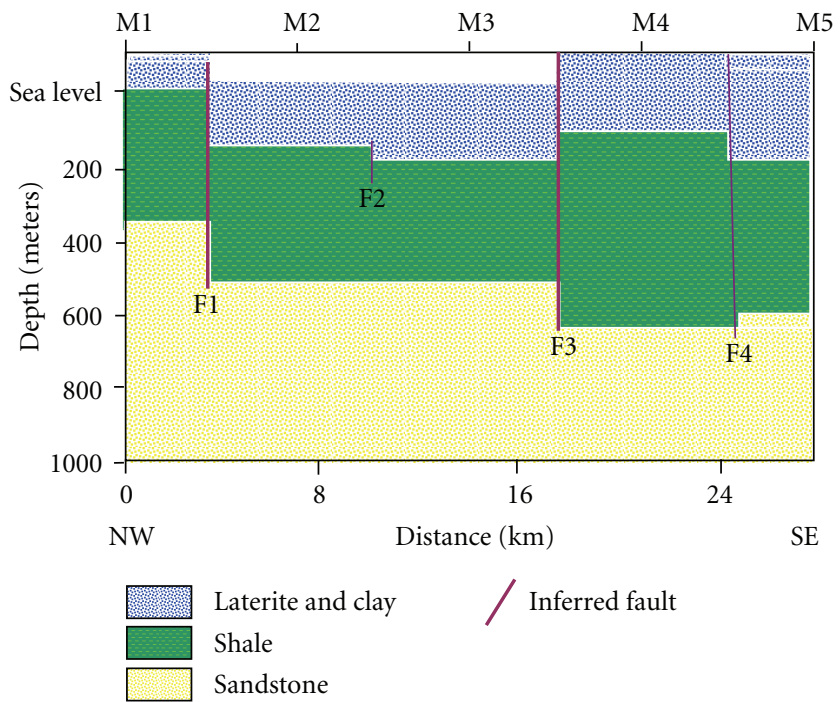

FIGURE 6: Geological section along Manyu River, showing probable stratigraphy and formation.

5.3. Structural Interpretation. Our structural interpretation is based on the pseudosection (Figure 4) and the geoelectric section (Figure 5) that enables us to derive a geological section (Figure 6).

The apparent resistivity pseudosection (Figure 4) helps to constrain the underground continuity of geological

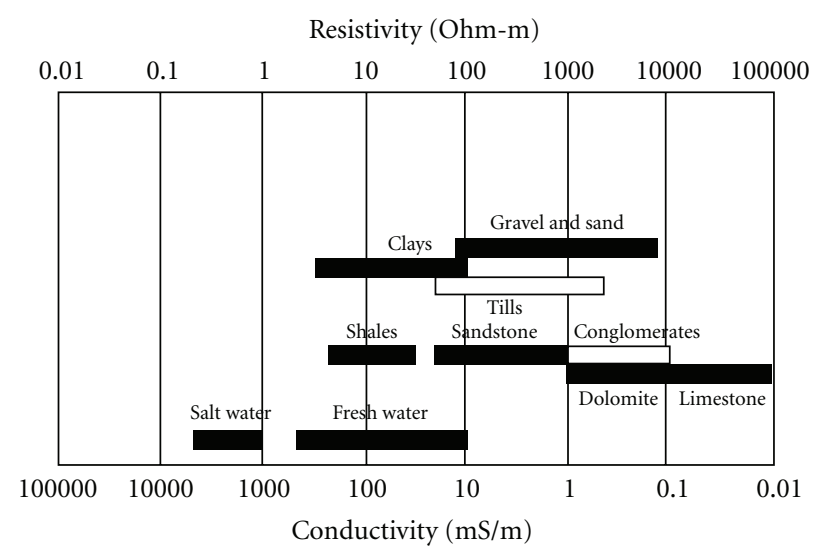

FIGURE 7: Resistivity of geological formations from [42].

structures and formations. In this type of representation, the distances between stations are displayed in the abscissa (linear scale), and the square roots of the periods are displayed in the ordinate (logarithmic scale) $[11,12,17]$. It can be observed that the variations in resistivities are slightly contrasted at the surface. These variations highlight three major superficial discontinuities in M2, M3, and M4. The pseudosection also shows a regular decrease of the resistivity with the period, thus suggesting the occurrence of conductive rocks at greater depths. These relatively conductive layers are characterized by resistivities that are lower than 17 Ohm-m. The conductive layers stretch across the pseudosection.

The geoelectric section (Figure 5) shows the electrical resistivity model which bestfits AMT responses along the profile. This model displays a relatively conductive zone with electrical resistivities ranging from 1 to $100 \mathrm{Ohm}-\mathrm{m}$, located down to a depth of about $1000 \mathrm{~m}$. The model highlights a layer whose electrical resistivities vary between 1 and 3 Ohm$\mathrm{m}$ (in black). This layer has a depth, which varies between 100 and $200 \mathrm{~m}$ and can be related to conductive layers previously mentioned in the interpretation of sounding curves. This layer is sandwiched between two layers with electrical resistivity 10 to $100 \mathrm{Ohm}-\mathrm{m}$ and thickness 100 to $200 \mathrm{~m}$, and with deeper layers characterized by lower electrical resistivities (20 Ohm-m).

Although the model does not allow delineation of the granite-gneiss basement geometry, it helps to locate the limits of the geological formations and the fractured zones cutting the profile, either by a reduction or an increase in the electrical resistivity. As a whole, this geoelectric section helped to conceive the geologic section of the first $1000 \mathrm{~m}$ of this part of the basin.

In the absence of borehole data, which are generally necessary for this kind of interpretation $[36,40,41]$, the geoelectrical section (Figure 5), which was obtained by correlating 1D models at each station, was compared with rocks' resistivity (Figure 7) and the lithostratigraphic column of the eastern part of the Mamfe basin proposed by Le Fur [25] and Eseme et al. [23] (Figure 2) to deduce a geological section (Figure 6) along the profile. The geological section in Figure 6 highlights three different resistivity layers. The first layer, which is the combination of the first two layers 
TABle 1: Geographic coordinates of the measuring sites. The geodetic system used to locate the stations is WGS 84, and the system of projection used is UTM (Universal Transverse Mercator). The latitudes and longitudes are in degree.

\begin{tabular}{lccc}
\hline Stations & Longitude $^{\circ} \mathrm{E}$ & Latitude $^{\circ} \mathrm{N}$ & Elevation $(\mathrm{m})$ \\
\hline NDWAP (M1) & $009^{\circ} 03.920$ & $05^{\circ} 56.151$ & 100 \\
ABONANDO (M2) & $009^{\circ} 06.985$ & $05^{\circ} 53.820$ & 50 \\
ESAGEM1 (M3) & $009^{\circ} 11.846$ & $05^{\circ} 52.574$ & 50 \\
ESAGEM2 (M4) & $009^{\circ} 15.091$ & $05^{\circ} 47.664$ & 120 \\
BAKU (M5) & $009^{\circ} 18.360$ & $05^{\circ} 48.007$ & 89 \\
\hline
\end{tabular}

identified on the 1D models and geoelectric section (Figures 3 and 5), has an average thickness of approximately $200 \mathrm{~m}$ with resistivities in the range $20-100 \mathrm{Ohm}-\mathrm{m}$. This layer can be associated with mixture of laterite and clay of Tertiary age $[11,12,23]$. The second layer has an average thickness of $400 \mathrm{~m}$ with resistivities in the range of approximately 1 to $3 \mathrm{Ohm}-\mathrm{m}$. It can be due to the black shale of Manyu $[11,12,23]$. The third layer has an average thickness of $500 \mathrm{~m}$ with resistivities that range from 3 to $20 \mathrm{Ohm}-\mathrm{m}$; it can be associated with sandstones of Albian age $[11,12,23]$. We also identified four discontinuities between stations M1 and M5, which appear to correlate with faults of geological map (Figure 1(b)) or a change in altitude (Table 1). The geological map shows a fault between stations M2 and M3 and between M4 and M5. We interpret the fault between M2 and M3 (F2) to be located at about $150 \mathrm{~m}$ depth below the surface. The fault between M4 and M5 (F4) is characterized in our model by a discontinuity. Another discontinuity is observed between stations M3 and M4, and we postulate that this discontinuity may also be due to a fault (F3). It should be noted that, due to the relatively large spacing between stations $(5 \mathrm{~km})$, the precise delimitation of these faults is not possible.

\section{Discussion}

We identified three major resistivity layers covering a depth of 7 to $1000 \mathrm{~m}$, with low resistivities in the range 1 to $100 \mathrm{Ohm}-\mathrm{m}$, indicating the conductive nature of the subsurface in this part of the basin. The models in Figures 3 and 5 show a progressive decrease in resistivity with depth. The granite-gneiss basement characterize by greater resistivity values seems sufficiently far from the surface in our models. The gravity studies of Fairhead et al. [7] and Ndougsa-Mbarga [8] showed that the depth of the basin can vary between $700 \mathrm{~m}$ to $3000 \mathrm{~m}$ at different sites of the basin. Based on the geoelectrical section, we can conclude that sedimentary layer can exceed $1000 \mathrm{~m}$ thickness.

The results of Nouayou [12] and Tabod et al. [13] predict the occurrence of volcanic rocks in the southern part of the basin with resistivities that vary between 250 and $1000 \mathrm{Ohm}$ $\mathrm{m}$ and depths 30 to $100 \mathrm{~m}$. We did not see evidence for shallow volcanic rocks in our profile because the resistivity values are well below $250 \mathrm{Ohm}-\mathrm{m}$.

\section{Conclusion}

The use of the audiofrequency magnetotellurics technique enables the identification of faults and sediments of low resistivities in the Mamfe basin, along the Manyu River. We use a combination of a pseudosection, sounding curves, and a geoelectrical section to derive a geological interpretation of the area. We identified three main layers of low resistivities (1-100 Ohm-m), covering a depth of 800-1000 m. Based on correlation of our derived resistivities with rocks, we interpreted the shallowmost layer to be made of laterite and clay, the following second layer to be made of shale, and the third layer to be made of sandstone. Our interpretation of faults, which is based on discontinuities in the derived geoelectric section, illustrates the structural complexity of the basin. These results give an insight of the geological structure of the Mamfe basin along the Manyu River, which can be useful in the future for mining or hydrocarbon exploration.

\section{Acknowledgment}

The authors thank IRGM and SNH for the authorization to use the data set used in this paper.

\section{References}

[1] Lagas, 1993, Laboratoire de Géophysique Applique et structurale du CNRS.

[2] J. C. Dumort, "Carte géologique de reconnaissance à l'échelle $1 / 500000$. Note explicative sur la feuille Douala-Ouest. République fédérale du Cameroun," Direction des Mines et de la Géologie du Cameroun, p. 69, 1968.

[3] Paterson, Grant and Watson, "Etudes aéromagnétiques sur certaines régions de la République Unie du Cameroun," Rapport d'interprétation, Agence Canadienne de Développement International, Toronto, Canada, 1976.

[4] F. Collignon, Gravimétrie de reconnaissance de la République Fédérale du Cameroun, Ostrom, Paris, France, 1968.

[5] J. D. Fairhead and C. S. Okereke, "A regional gravity study of the West African rift system in Nigeria and Cameroon and its tectonic interpretation," Tectonophysics, vol. 143, no. 1-3, pp. 141-159, 1987.

[6] J. D. Fairhead and C. S. Okereke, "Depths to major density contrats beneath the West African rift system in Nigeria and Cameroon based on the spectral analysis of gravity data," Journal of African Earth Sciences, vol. 7, no. 5-6, pp. 769-777, 1988.

[7] J. D. Fairhead, C. S. Okereke, and J. M. Nnange, "Crustal structure of the Mamfe basin, West Africa, based on gravity data," Tectonophysics, vol. 186, no. 3-4, pp. 351-358, 1991.

[8] T. Ndougsa-Mbarga, Etude géophysique, par méthode gravimétrique des structures profondes et superficielles de la région de Mamfé, Thèse de Doctorat, Faculté des Sciences, Université de Yaoundé I, Yaoundé, Cameroun, 2004.

[9] T. Ndougsa-Mbarga, E. Manguelle-Dicoum, J. O. CamposEnriquez, and Q. Y. Atangana, "Gravity anomalies, sub-surface structure and oil and gas migration in the Mamfe, CameroonNigeria, sedimentary basin," Geofisica Internacional, vol. 46, no. 2, pp. 129-139, 2007.

[10] E. Manguelle-Dicoum, R. Nouayou, C. Tabod, and T. E. Kwende-Mbanwi, "Audio and helio magnetotelluric study of the Mamfe sedimentary basin,” Tech. Rep., 1999. 
[11] J. J. Nguimbous-Kouoh, Apport de l'audio-magnétotellurique (AMT) pour l'Etude des couches superficielles le Long du Fleuve Manyu, Mémoire de DEA, Faculté des Sciences, Université de Yaoundé I, Yaoundé, Cameroun, 2003.

[12] R. Nouayou, Contribution à l'étude géophysique du bassin sédimentaire de Mamfe par prospections audio et hélio magnétotelluriques, M.S. thesis, spécialité Géophysique Interne, Université de Yaoundé I, Yaoundé, Cameroun, 2005.

[13] C. T. Tabod, A. P. Tokam Kamga, E. Manguelle-Dicoum, R. Nouayou, and S. Nguiya, An Audio-Magnetotelluric Investigation of the Eastern Margin of the Mamfe Basin, Cameroon, The Abdus Salam International Centre for Theoretical Physics, Trieste, Italy, 2008.

[14] A. Dupis, Première Application de la Magnétotellurique à la Prospection Pétrolière, Doctorat d'état ès-sciences, Géologique ou Minière de diverses régions Métropolitaines, 1970.

[15] Y. Benderritter, Interprétation des mesures magnétotelluriques à l'aide d'un résistivimètre ECA, Centre de recherches géophysiques, Nièvre, France, 1982.

[16] P. Andrieux, 1987, Application des Sondages Magnétotellurique à l'exploration à moyennes et à grandes profondeurs. Dossier présenté en appui à une demande d'habilitation à diriger des recherches (U.P.M.C., Paris VI).

[17] A. Bobachev, IPI2WIN in (MT) V.2.0 Is Designed for Automated and Interactive Semi-Automated Interpreting of Magnetotelluric Sounding Data Using Amplitude and/or Phase Curves, Geoscan-M, Moscow, Russia, 2001.

[18] Pitisharvi, 2004, AMTINV for automated and interactive 1D interpretation of audio-magnetotelluric EM soundings Version 1.3 (c).

[19] M. M. Eben, "Report of the geological expedition in the gulf of Mamfe: archives of the department of mines \& geology," Tech. Rep., Ministry of Mines \& Power, Douala, Cameroon, 1984.

[20] J. V. Hell, V. Ngako, V. Bea, J. B. Olinga, and J. T. Eyong, "Rapport des travaux sur l'étude de reconnaissance géologique du bassin sédimentaire de Mamfé: IRGM-SNH,” Tech. Rep., 2000.

[21] J. T. Eyong, Litho-Biostratigraphy of the Mamfe Cretaceous Basin, Communication of the Department of Earth Sciences, Faculty of Science University of Yaoundé I, Yaoundé, Cameroon, 2001.

[22] R. Kangkolo, "Aeromagnetic study of the Mamfe basalts of southwestern Cameroon," Journal of the Cameroon Academy of Sciences, vol. 2, no. 3, pp. 173-180, 2002.

[23] E. Eseme, C. M. Agyingi, and J. Foba-Tendo, "Geochemistry and genesis of brine emanations from Cretaceous strata of the Mamfe Basin, Cameroon," Journal of African Earth Sciences, vol. 35, no. 4, pp. 467-476, 2002.

[24] R. Kangkolo and S. B. Ojo, "Integration of aeromagnetic data over the Mamfe basin of Nigeria and Cameroon," Nigeria Journal of Physics, vol. 7, pp. 53-56, 1995.

[25] Y. le Fur, "Mission socle-Crétacé. Rapport 1964-1965 sur les indices de plomb et zinc du golfe de Mamfe," Tech. Rep., Rapport B.R.G.M., Cameroun, 1965.

[26] A. N. Tikhonov, "On determining electrical characteristics of the deep layers of the earth's crust," Doklady Akademii Nauk, USSR, vol. 73, no. 2, pp. 295-297, 1950.

[27] L. Cagniard, "Basic theory of the magnetotelluric method in geophysical prospecting," Geophysics, vol. 18, no. 3, pp. 605635, 1953.

[28] K. Vozoff, "The magnetotelluric method," in Electromagnetic Methods in Applied Geophysics, M. N. Nabighian, Ed., vol. 2, part B, pp. 641-711, Society of Exploration Geophysicists, Tulsa, Okla, USA, 1991.
[29] M. Bastani, EnviroMT New Controlled Source/Radio Magnetotelluric, Ph.D. thesis, Uppsala University, Uppsala, Sweden, 2001.

[30] M. Bastani and L. B. Pedersen, "Estimation of magnetotelluric transfer functions from radio transmitters," Geophysics, vol. 66, no. 4, pp. 1038-1051, 2001.

[31] J. M. Travassos and P. T. L. Menezes, "Geoelectric structure beneath limestones of the Sao Francisco Basin, Brazil," Earth, Planets and Space, vol. 51, no. 10, pp. 1047-1058, 1999.

[32] L. B. Pedersen and M. Engels, "Routine 2D inversion of magnetotelluric data using the determinant of the impedance tensor," Geophysics, vol. 70, no. 2, pp. G33-G41, 2005.

[33] A. G. Jones, "Static shift of magnetotelluric data and its removal in a sedimentary basin environment," Geophysics, vol. 53, no. 7, pp. 967-978, 1988.

[34] L. Pellerin and G. W. Hohmann, "Transient electromagnetic inversion: a remedy for magnetotelluric static shifts," Geophysics, vol. 55, no. 9, pp. 1242-1250, 1990.

[35] E. Manguelle-Dicoum, R. Nouayou, A. S. Bokosah, and T. E. Kwende-Mbanwi, "Audiomagnetotelluric soundings on the basement-sedimentary transition zone around the eastern margin of the Douala Basin in Cameroon," Journal of African Earth Sciences, vol. 17, no. 4, pp. 487-496, 1993.

[36] M. Chouteau, P. Zhang, D. J. Dion, B. Giroux, R. Morin, and S. Krivochieva, "Delineating mineralization and imaging the regional structure with magnetotellurics in the region of Chibougamau (Canada)," Geophysics, vol. 62, no. 3, pp. 730-748, 1997.

[37] X. Garcia and A. G. Jones, "A new methodology for the acquisition and processing of audio-magnetotelluric (AMT) data in the dead band," Geophysics, vol. 70, no. 5, pp. 119-126, 2005.

[38] P. Zhang, R. G. Roberts, and L. B. Pedersen, "Magnetotelluric strike rules," Geophysics, vol. 52, no. 3, pp. 267-278, 1987.

[39] M. Hjärten, Master thesis in interpretation of controlled-source radiomagnetotelluric data from Hallandsåsen, M.S. thesis, Uppsala universitet Institutionen för Geovetenskaper-Geofysik, Uppsala, Sweden, 2007.

[40] T. Dahlin, "2D resistivity surveying for environmental and engineering applications," First Break, vol. 14, no. 7, pp. 275283, 1996.

[41] J. Pratt and J. Craven, 2010, magnetotelluric imaging of the Nachako basin, Bristish Colombia. Geological survey of Canada, Current research 2010-3, 9p.

[42] Bemex Consulting International, Interpretation of Apparent Resistivity Maps and Resistivity cross Sections from the Kotcho Region, N.E. British Columbia, British Columbia Ministry of Energy and Mines, British Columbia, Canada, 2004. 

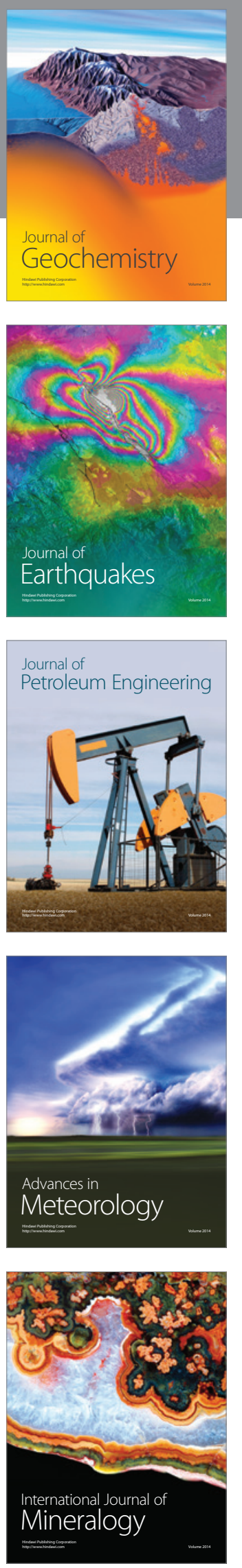
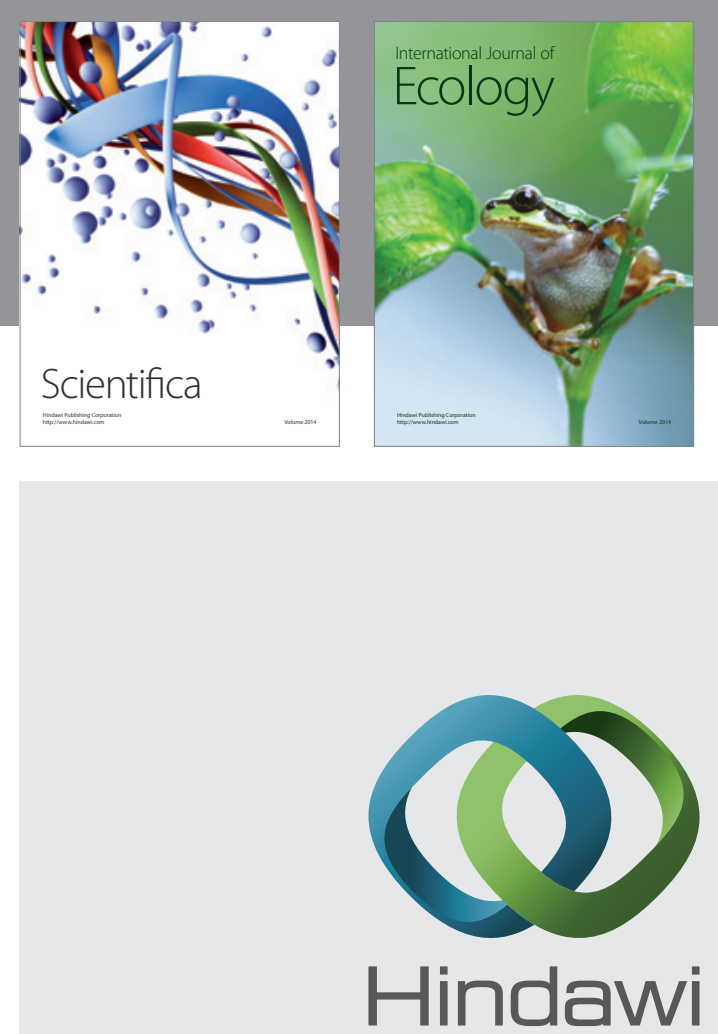

Submit your manuscripts at http://www.hindawi.com
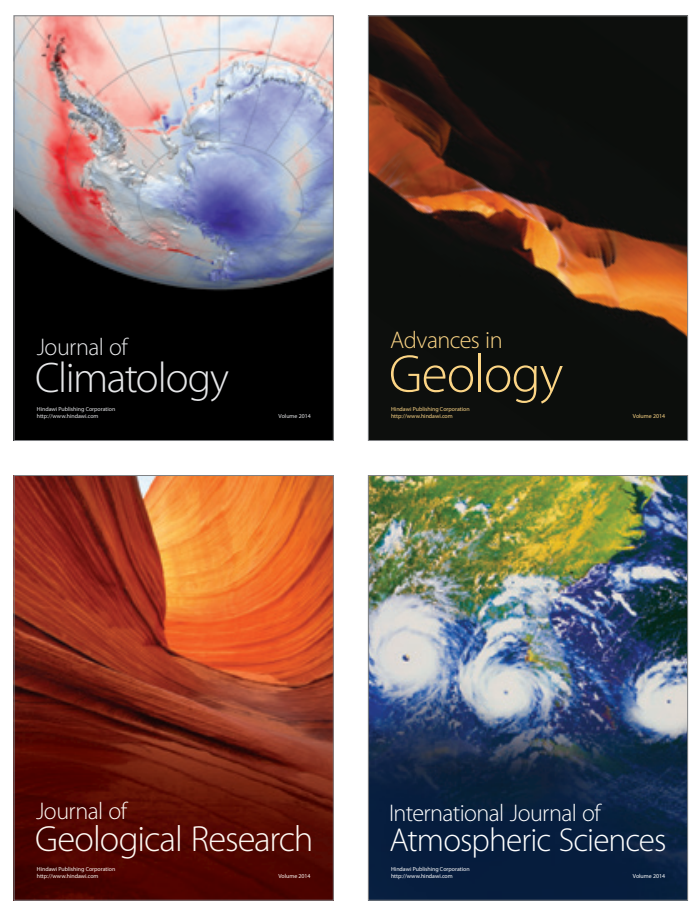
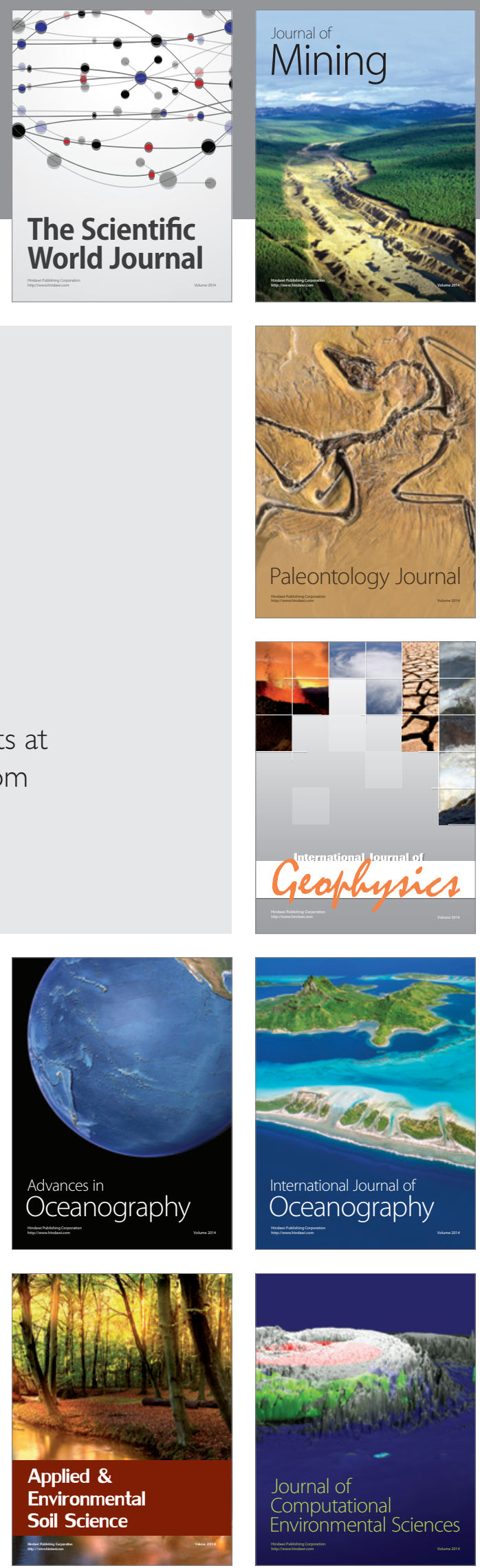